Article

\title{
Survival of Whitebark Pine Seedlings Grown from Direct Seeding: Implications for Regeneration and Restoration under Climate Change
}

\author{
Elizabeth R. Pansing *(D) and Diana F. Tomback (D) \\ Department of Integrative Biology, Campus Box 171, University of Colorado Denver, P.O. Box 173364, \\ Denver, CO 80217-3364, USA \\ * Correspondence: elizabeth.pansing@ucdenver.edu
}

Received: 12 June 2019; Accepted: 2 August 2019; Published: 11 August 2019

\begin{abstract}
Whitebark pine populations are declining nearly range-wide, primarily from the exotic fungal pathogen that causes white pine blister rust (WPBR). Climate change is expected to exacerbate these declines by decreasing climatically suitable areas. Planting WPBR-resistant seedlings is a key restoration action, but it is costly, time consuming, and labor intensive. Direct seeding-sowing seeds rather than planting seedlings-may reduce costs and open remote areas to restoration; however, its efficacy remains largely unexplored. In this case study, we estimated the annual survival rates (ASR) of seedlings grown from directly sown seeds, and the effect of elevation zone and microsite type on survival. For five years we monitored 184 caches containing one or more seedlings within one study area in the Greater Yellowstone Ecosystem. Seed caches were originally stratified between subalpine forest and treeline and among three microsite types defined by a nurse object: Rocks, trees, and no object. To estimate ASR, we selected the most parsimonious model of a set using AICc. ASR was best described by elevation zone and year and ranged from 0.571 to 0.992 . The odds of seedling survival were 2.62 times higher at treeline than in subalpine forest and were 4.6 to 36.2 times higher in 2016-2018 than 2014. We estimated the probability that a whitebark pine seed cache would contain one or more living seedlings six years after sowing to be 0.175 and 0.0584 for treeline and subalpine caches, respectively. We estimated that 1410 and 4229 caches ha $^{-1}$ would need to be sown at treeline and in subalpine forest, respectively, to attain target restoration densities of 247 established trees $\mathrm{ha}^{-1}$. Our findings, although based on one study area, suggest that climate change may be increasing treeline regeneration, and that direct seeding may be a viable restoration option and climate change mitigation tool for whitebark pine.
\end{abstract}

Keywords: whitebark pine; Pinus albicaulis; regeneration; restoration; direct seeding; seedling survival; treeline; climate change

\section{Introduction}

In recent decades, many forest species have experienced substantial population declines caused by exotic and native pests and pathogens, and climate change mediated alterations to demographic rates and disturbance regimes [1-8]. These declines reduce biodiversity, disrupt ecosystem function, and threaten ecosystem services $[9,10]$. Whitebark pine (Pinus albicaulis Engelm), an upper subalpine and treeline conifer distributed throughout western North America, is declining nearly range-wide because of the combined impacts of the exotic fungal pathogen Cronartium ribicola J.C. Fisher, which causes the often fatal disease white pine blister rust (WPBR), outbreaks of the native mountain pine beetle (MPB; Dendroctonus ponderosae Hopkins), successional replacement from fire suppression, and the effects of changing fire regimes [11-16]. In the aggregate, these threats have resulted in tree 
mortality that varies geographically but exceeds $90 \%$ in some locations $[13,15,17,18]$. Further, climate change is predicted to reduce climatically suitable areas for whitebark pine, shifting its distributional center up in elevation and northwards [19-23]. Seed availability, successful seed dispersal by Clark's nutcracker (Nucifraga columbiana Wilson) — the primary seed disperser for whitebark pine-and increased regeneration in areas expected to become distributional centers will be necessary for whitebark pine to track suitable climates and claim newly available habitat [20,24-27].

Tree mortality and canopy kill from WPBR leads to declining seed availability, which is compounded by predispersal seed predation, especially of small cone crops $[15,25,28-30]$. As a keystone and foundation species that facilitates plant establishment and growth, fosters community development, prevents erosion, protracts snow melt, and provides food and habitat for a variety of species [16,31,32], whitebark pine's decline has widespread consequences for entire ecosystems $[25,33]$. Conservation and restoration strategies are being developed across whitebark pine's range to slow population declines and prevent widespread impacts to ecosystem function [11,33]. Restoration actions focus on speeding up natural selection for WPBR resistance and supplementing populations until natural regeneration can maintain viable population sizes and resistance [34-36]. These goals are accomplished by planting putative pathogen-resistant stock, the principal restoration action for whitebark pine and other forests impacted by exotic pests and pathogens [34-37]. Increasing the prevalence of WPBR-resistant individuals on the landscape begins by identifying likely WPBR-resistant (i.e., relatively healthy) individuals in areas with high incidence of WPBR. Seeds are germinated in a nursery; seedlings are exposed to WPBR spores and are monitored for infection symptoms. Seedlings that show resistance are tracked back to specific parent trees, and their seeds are used to grow seedlings for restoration planting, seed orchard development, genetic conservation, and clone bank contributions $[37,38]$. Seedlings for restoration planting are grown for two to three years in a nursery before they are outplanted [35,39-41].

Although planting seedlings is a key restoration action, the process is time and work intensive, costly, and logistically challenging. Time from seed collection to outplanting is a minimum of three years. Seeds are collected during the fall and treated to break dormancy; germination occurs the following spring/summer; and, seedlings are grown in the nursery for two to three years before planting occurs. This process, and the planting itself, costs roughly between $\$ 1980$ to $\$ 2400$ (USD) per ha [42], a challenge for already underfunded land-management agencies. Further, planting is restricted to accessible locations where land management agency guidelines allow for restoration activities. In wilderness areas, which comprise $48 \%$ of whitebark pine habitat in the U.S., access is often difficult due to remoteness, and prohibited use of mechanical equipment and motorized transport. Planting seedlings in remote areas requires packing seedlings in by horses or mules, or with helicopter support, which is not possible in designated wilderness areas. Even without accessibility hurdles, wilderness regulations in many locations do not allow planting, although some regions of the US Forest Service are developing planting guidelines $[35,43,44]$.

Because of the limitations to restoration planting, direct seeding (sowing seeds) has been explored in some systems to reduce costs, increase efficiency, and expand restoration into remote areas, because it reduces the equipment necessary for planting and avoids some of the arguments against seedling planting in wilderness areas. Germination probabilities from whitebark pine direct seeding experiments have ranged from 0.13 to 0.85 over one to three years (a result of delayed germination) [45-48], encouraging the potential use of this restoration option in some areas. However, there has been little follow-up on the survival of seedlings produced from sown seeds and especially the microsite conditions that favor survival. Previous studies have investigated survival of seedlings produced by direct seeding efforts for a maximum of three years, but seedling mortality is expected to remain high for up to five years after germination [49-51]. Consequently, the potential long-term success of direct seeding remains unknown, and additional monitoring is necessary to evaluate whether direct seeding is a viable restoration option for whitebark pine. 
In early 2012, Pansing et al. [45] established a direct seeding study at two locations in the Northern Rocky Mountains to assess spatial distribution changes of cached seeds and young whitebark pine regeneration caused by rodent seed pilferage, microsite type and elevation zone. Caches of sown whitebark pine seeds were monitored for seed pilferage, germination, and first-year seedling survival. Continued monitoring presented an opportunity to assess rigorously the survival of seedlings produced from sown seeds and to evaluate the efficacy of direct seeding. Here, we present the results of five years of monitoring seedlings grown from seeds sown by Pansing et al. [45]; these data enabled us to estimate annual whitebark pine seedling survival, determine whether site-specific characteristics influenced annual survivorship, and provide guidelines for whitebark pine restoration efforts through direct seeding.

\section{Materials and Methods}

\subsection{Study Area}

In early August 2012, Pansing et al. [45] sowed seeds at two locations in the Northern Rocky Mountains. From 2013 to 2018, we monitored seedlings produced from that seeding effort at one of the

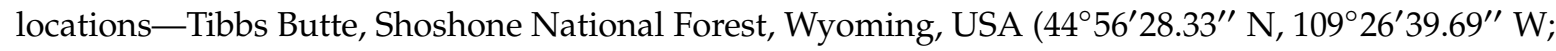
Figure 1). Tibbs Butte is a rocky prominence located approximately $4 \mathrm{~km}$ southeast of Beartooth Pass summit, east of the Continental Divide, and within the Greater Yellowstone Ecosystem (GYE). Elevations within the study area range from 2980 to $3240 \mathrm{~m}$ and encompass both upper subalpine and treeline forest. A detailed description of the study area including the plant community composition is presented in $[32,45,52]$.

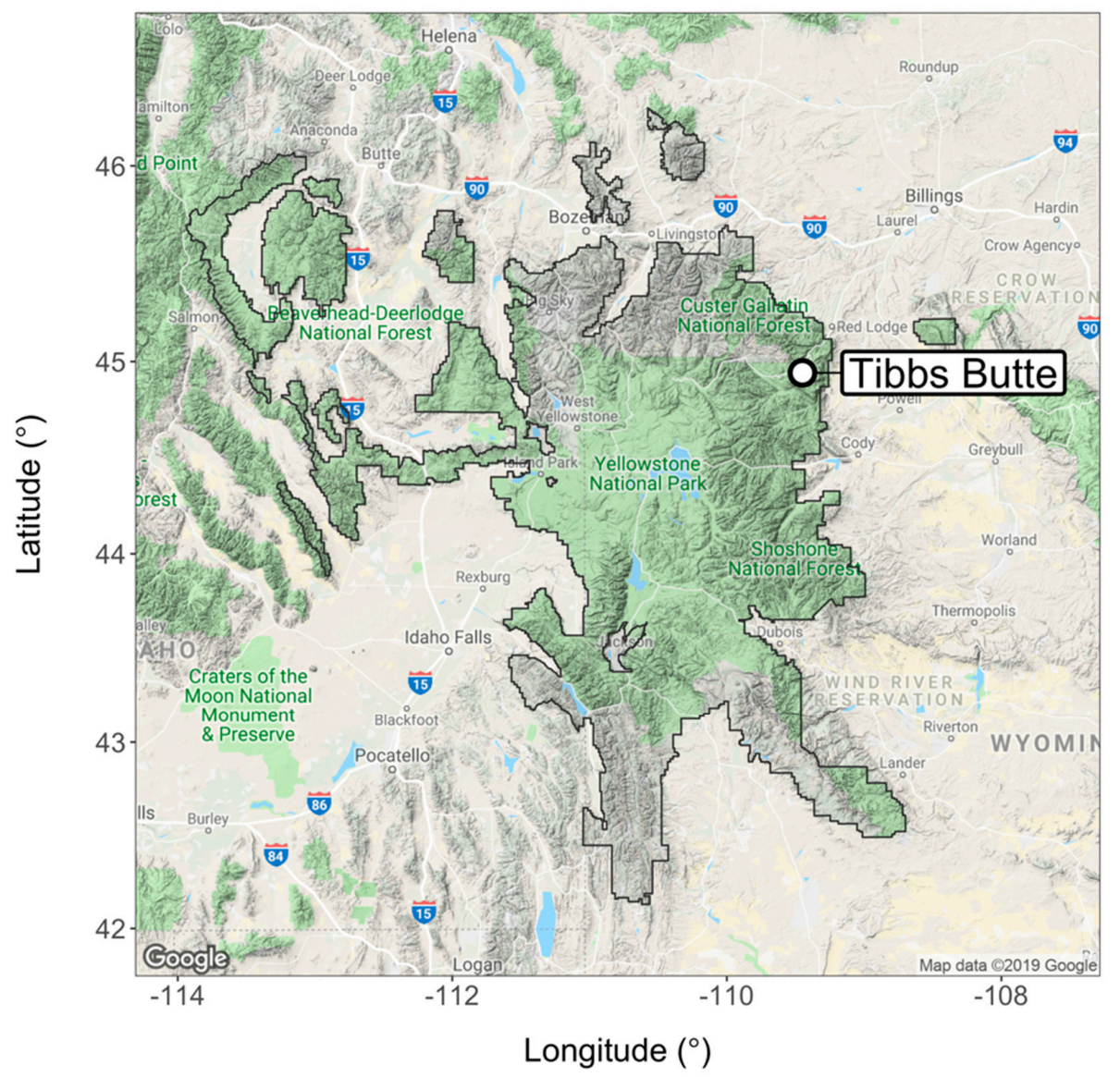

Figure 1. Geographic location of the study area, Tibbs Butte, Shoshone National Forest, Wyoming. The shaded polygons represent the Greater Yellowstone Ecosystem [53,54]. Map courtesy of Google. Figure created using the ggmap [55] and ggplot2 [56] packages in R [57]. 
During the study, air temperatures at the Beartooth Lake SNOTEL station [58], which is approximately $11 \mathrm{~km}$ west of Tibbs Butte at an elevation of $2850 \mathrm{~m}$, ranged from -36.3 to $26.5^{\circ} \mathrm{C}$. The growing season, defined as the time period between five consecutive days of mean daily air temperature above $5{ }^{\circ} \mathrm{C}$ and five consecutive days of mean daily air temperature below $5{ }^{\circ} \mathrm{C}$ [59] extended from approximately 30 May to 15 October each year. Median daily average growing season temperature during the study was $9.4^{\circ} \mathrm{C}$, whereas median daily average temperature during the non-growing season was $-4.5^{\circ} \mathrm{C}$ (Figure 2). Cumulative water year precipitation ranged from $68.1 \mathrm{~cm}$ during the 2015 water year to $124 \mathrm{~cm}$ during the 2018 water year and averaged $96.1 \mathrm{~cm}$ per water year (Figure 3).

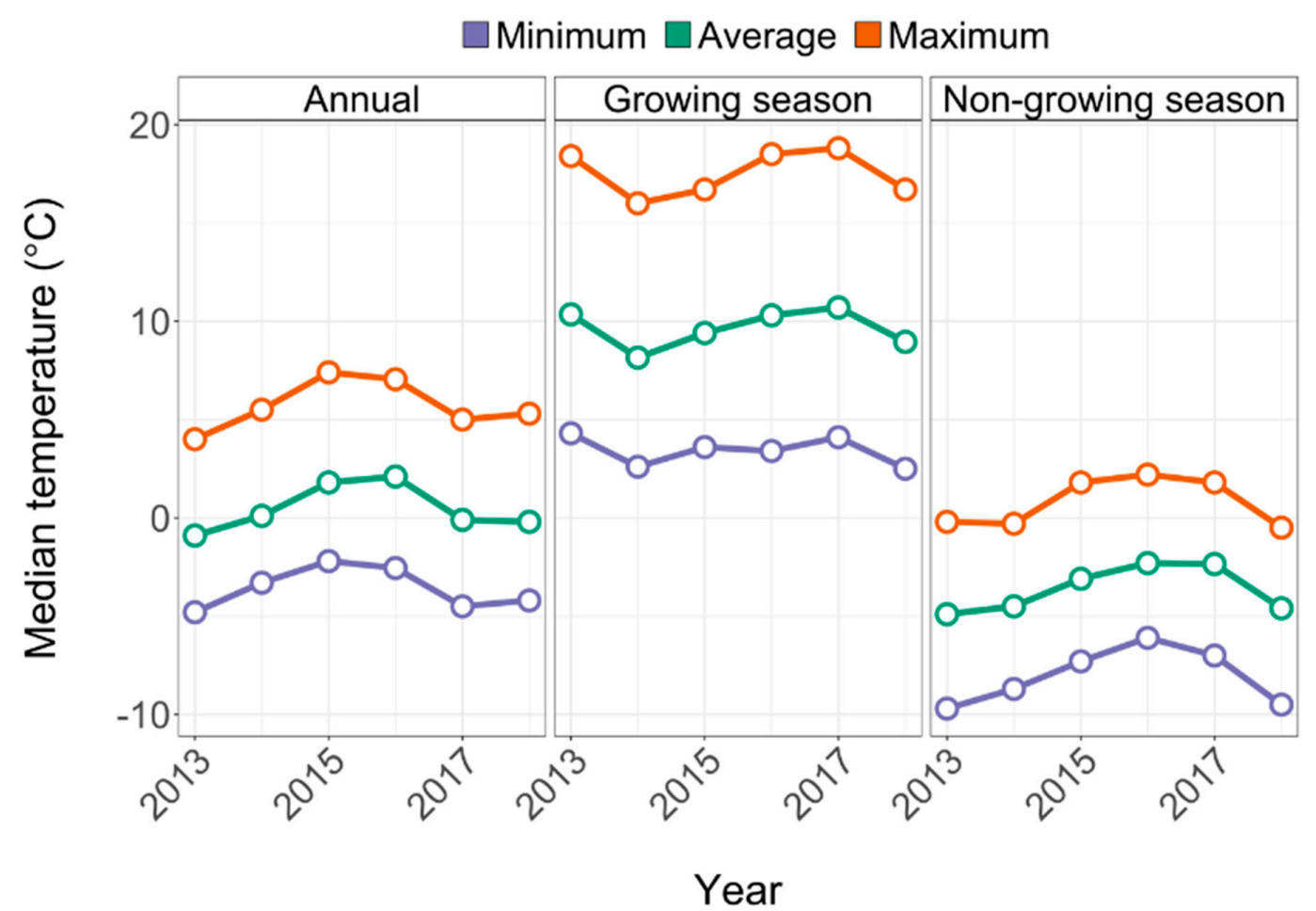

Figure 2. Median annual daily minimum, average, and maximum temperatures throughout the study period. Panels show temperatures aggregated annually, over each year's growing season, and over each year's non-growing season. We defined the growing season as the time period between five consecutive days of mean daily air temperature above $5^{\circ} \mathrm{C}$ and five consecutive days of mean daily air temperature below $5^{\circ} \mathrm{C}$.

\subsection{Direct Sowing and Cache Surveys}

Seeds were collected in September 2011 from Line Creek Research Natural Area, Custer Gallatin National Forest, Montana, approximately $11 \mathrm{~km}$ north-northeast of Tibbs Butte. Proximity to Tibbs Butte preserved local genetic adaptation [60]. We did not assess the trees from which cones were collected for WPBR-resistance or WPBR symptoms. Seed processing and storage details are presented in [45]. 


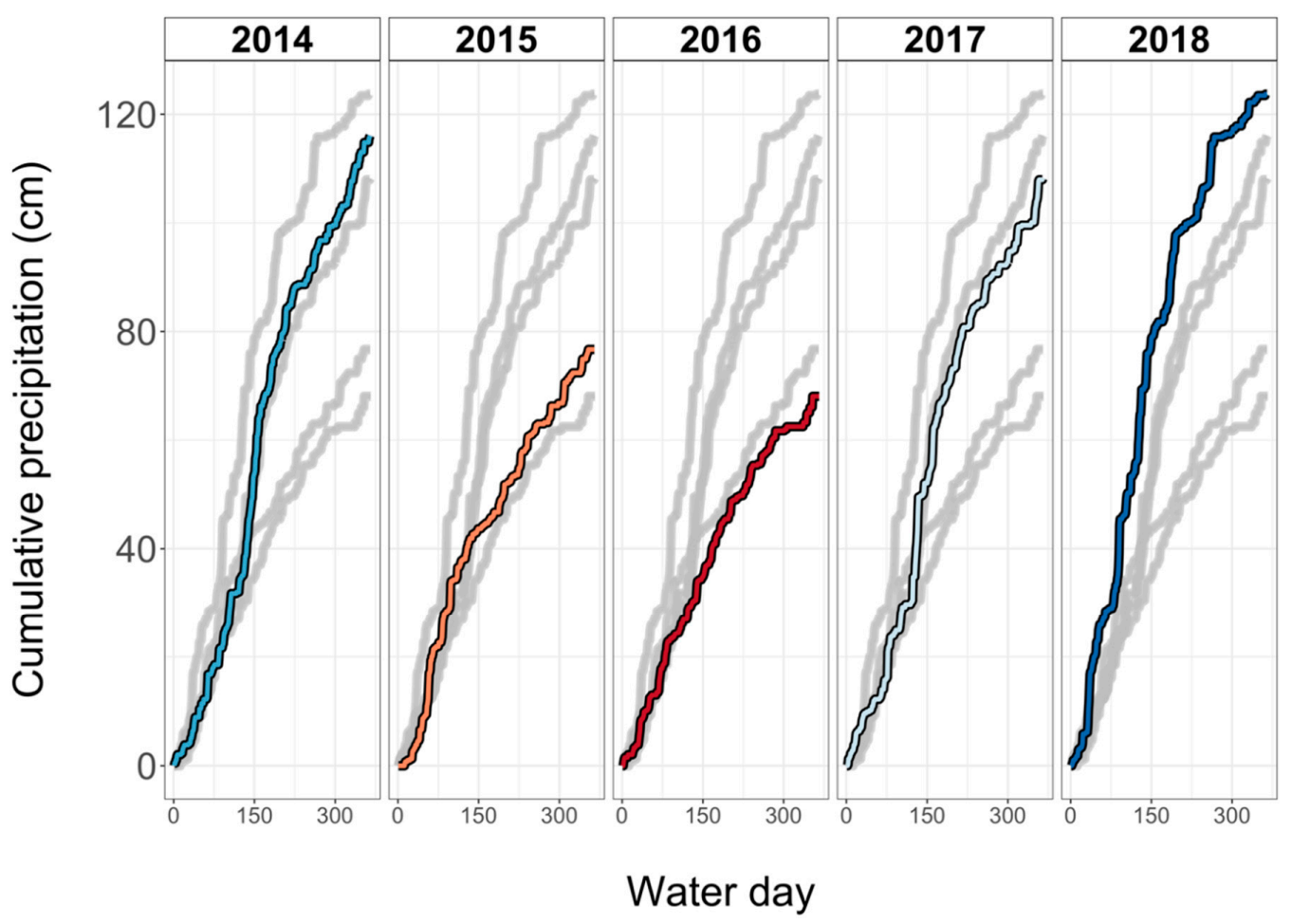

Figure 3. Cumulative precipitation during each water year (1 October through 31 September) of the study. Data shown are the values recorded at the Beartooth Lake SNOTEL site [58], which is located approximately $11 \mathrm{~km}$ from Tibbs Butte. Water year data adequately capture the period between study surveys, which occurred each year during early August. Grey lines in each panel show other water years and are intended to allow for comparison among water years.

In late July through early August 2012, Pansing et al. [45] created whitebark pine seed caches on Tibbs Butte, stratified by elevation zone and nurse object (rock, tree, or no object (exposed)). Caches were buried $\sim 10 \mathrm{~cm}$ from the closest systematically assigned object type to a random point location selected using the random sampling tool in ArcGIS [61]. Seeds were sowed approximately $2.5 \mathrm{~cm}$ below the soil surface, the average depth of nutcracker caches [27]. The number of seeds per cache was drawn randomly from a constrained Poisson distribution whose parameter was estimated from cache size data $(\lambda=3$, range $=1-7)[25,27]$. Each cache site was georeferenced using a Trimble GeoXT (GeoExplorer 2008 series). Exact cache locations were triangulated using two nail spikes located $\sim 21 \mathrm{~cm}$ from the cache, with the cache located in the vertex of a $90^{\circ}$ angle between nail spikes. Nail spikes aided in locating caches and seedlings in subsequent years.

Each August from 2013 through 2018, we assessed cache status. In 2013, we excavated every cache without disturbing newly germinated seedlings to determine whether intact seeds remained. Nail spikes were left in place if we found intact seeds and/or seedlings. Nail spikes were left in place when intact seeds were found, because whitebark pine seeds often delay germination; age differences of up to eight years between seedlings within the same cache have been documented [62]. In all other years, we only recorded the presence of one or more seedlings and the number of seedlings in each cache. We removed nail spikes if no living seedlings were found; these caches were not visited in subsequent years. Here we focus on 184 caches from which one or more seedlings germinated in either 2013 or 2014. Germination rates are presented in Pansing et al. [45]. 


\subsection{Data Analysis}

We treated the cache as the sampling unit for analyses because multiple seedlings may germinate from the same cache, and these will often fuse to form one multi-stemmed individual tree $[63,64]$. Further, whitebark pine restoration success will be determined by the number of seed caches that successfully produce one or more seedlings. We therefore considered one or more living seedlings present in a cache a success. We estimated the annual survival rate (ASR) of caches comprising one or more seedlings and the effects of any covariates on ASR using known fate models and conducted analyses in program MARK using the RMark interface in R (version 3.5.1) [57,65-68]. For this class of models, the cache history is the response variable and parameters of a multinomial process are estimated numerically. Known fate models assume individual fates are independent (or modeled appropriately) and censoring (i.e., individuals whose fates are not known) is random. Known fate models produce parameter estimates that are equivalent to logistic regression. We used a multiple hypothesis testing framework to select which among our a priori hypotheses about whitebark pine seedling survival was most parsimonious [69,70]. We determined the relative support for each of our hypotheses using AICc, whereby the model with the lowest AICc value was considered the hypothesis with the most support given our model set and data [70]. We considered the models shown in Table 1, which explored the effect of cache site characteristics, including elevation zone, nurse object, and year on ASR of whitebark pine seedlings by cache. We do not consider the global model or all possible combinations of variables, because these methods often lead to overfitting and spurious results [70-72]. We checked for multicollinearity of explanatory variables and found no strong relationships.

Table 1. Set of known fate models defined a priori describing annual survival rate (ASR) of whitebark pine seedlings. Models were fit in program MARK using the RMark [65] interface in R [57]. ASR 1 indicates constant ASR.

\begin{tabular}{l}
\hline \multicolumn{1}{c}{ Model } \\
\hline ASR $\sim 1$ \\
ASR $\sim$ elevation zone + year \\
ASR $\sim$ elevation zone $\times$ nurse object \\
ASR $\sim$ nurse object + elevation zone + year \\
\hline
\end{tabular}

We included year in every model, because seedling survival varies over time for many conifer species (e.g., $[49,73])$ and to account for other annually varying covariates that we did not measure (e.g., weather, browsing). Year was included as a cofactor because we do not anticipate its impact to trend consistently over time. For example, precipitation varies annually but does not increase or decrease as a function of time. Elevation zone was also included in every model, because elevation can influence recruitment, and elevation effects were detected previously for this sample of seedlings [45]. The odds of seedlings surviving the first winter were 3.49 times higher at treeline relative to subalpine forest [45]. We included nurse object because seedling survival can be influenced by the presence and type of nurse object, and seedlings are often planted near nurse objects to improve restoration outcomes $[45,74,75]$. These observed patterns may persist through tree maturity, given that mature whitebark pine are not uniformly distributed among microsite types $[52,76,77]$. We did not include age as a covariate, despite expectations that seedling survival increases with age, because seeds within the same cache may have germinated in different years $[45,62,78]$. This confounded our ability to detect age effects. Because we treat cache as the sampling unit, age represented only the time since the first seed germinated. If mortality and additional germination occurred over time, the age of the cache would not represent the age of the seedlings within the cache. 


\section{Results}

By 2013, 139 of the original 372 caches created by Pansing et al. [45] contained one or more living seedlings. By 2014, one or more seeds germinated in an additional 45 of the caches as a result of delayed germination. Because our focus was on estimating survival of caches comprising living seedlings, our total sample size constituted 184 caches from which one or more seedlings germinated in either 2013 or 2014. By 2018, 37.0\% $(n=68)$ of the original 184 caches contained one or more living seedlings (Table 2). Over the course of the study, 22 caches could not be relocated during a survey; these caches were included in analyses only during periods for which their fates were known.

Table 2. Number of caches with one or more seedlings by year and elevation zone. Note that counts for 2014 represent both additional germination and mortality since 2013. One or more seedlings emerged from 45 caches in 2014 that had zero seedlings in 2013-21 at treeline and 24 in the subalpine forest.

\begin{tabular}{ccccccc}
\hline & \multicolumn{5}{c}{ No. Caches with 1+ Seedlings } \\
\cline { 2 - 7 } & $\mathbf{2 0 1 3}$ & $\mathbf{2 0 1 4}$ & $\mathbf{2 0 1 5}$ & $\mathbf{2 0 1 6}$ & $\mathbf{2 0 1 7}$ & $\mathbf{2 0 1 8}$ \\
\hline Treeline & 66 & 75 & 47 & 47 & 45 & 42 \\
Subalpine & 73 & 63 & 34 & 32 & 28 & 26 \\
TOTAL & $\mathbf{1 3 9}$ & $\mathbf{1 3 8}$ & $\mathbf{8 1}$ & $\mathbf{7 9}$ & $\mathbf{7 3}$ & $\mathbf{6 8}$ \\
\hline
\end{tabular}

The additive effect of elevation zone and year was the most parsimonious model (Table 3) and was followed by the additive effects of elevation zone, year, and object $(\triangle \mathrm{AICC}=1.26$; Table 3$)$. The top model indicated that elevation zone influenced ASR; odds of annual survival at treeline were 2.62 (95\% CI: 1.60, 4.26) times higher than within subalpine forest. Further, ASR increased relative to 2014 in all years except 2015 (Table 4, Figure 4). Relative to 2014, the odds of survival were 36.2 (95\% CI: 4.85, 269) times higher in 2016, 4.78 (95\% CI: 2.02, 11.3) times higher in 2017, and 5.09 (95\% CI: 2.03, 12.7) times higher in 2018. Annual survival rates estimated by the top model ranged from 0.571 ( $95 \% \mathrm{CI}$ : $0.470,0.667$ ) in the subalpine forest in 2014 to 0.992 (95\% CI: 0.945, 0.999) at treeline in 2016 (Figure 4). We estimated the probability of one or more recently germinated seedlings in a cache surviving from 2013 to 2018 in each elevation zone by multiplying the ASRs, resulting in five-year survival probabilities of 0.273 and 0.571 in the subalpine forest and at treeline, respectively, for this group of seedlings.

Table 3. Diagnostic statistics for all fitted models describing the probability of one or more seedlings per cache surviving each year (ASR) as functions of covariates including elevation zone, year, and nurse object. ASR 1 indicates constant ASR.

\begin{tabular}{cccccc}
\hline Model & Parameters & AICc & $\Delta$ AICc & Model Weight & Evidence Ratio \\
\hline$\sim$ year + elevation zone & 6 & 428.88 & - & 0.658 & - \\
$\sim$ year + elevation zone + object & 8 & 430.19 & 1.31 & 0.342 & 1.93 \\
$\sim$ object $\times$ elevation zone & 6 & 474.14 & 45.26 & $9.77 \times 10^{-11}$ & $6.73 \times 10^{9}$ \\
$\sim 1$ & 1 & 491.16 & 62.28 & $1.97 \times 10^{-14}$ & $3.35 \times 10^{13}$ \\
\hline
\end{tabular}

The model with the second lowest $\triangle \mathrm{AIC}$, which described ASR as an additive relationship between year, elevation zone, and nurse object indicated that, on average, caches near trees had higher ASR than those near rocks, and that ASR was lowest for caches near no nurse object (Table 4, Figure S1). However, the confidence intervals of all object parameters overlapped zero (Table 4). 
Table 4. Parameter estimates and 95\% confidence intervals (CIs) for the top two models describing annual survival rate (ASR).

\begin{tabular}{cccc}
\hline Model & Parameter & Estimate & $\mathbf{9 5 \%}$ CI \\
\hline & Intercept & 0.287 & $-0.122,0.696$ \\
& Treeline & 0.962 & $0.474,1.45^{*}$ \\
Elevation zone + year & 2015 & 0.326 & $-0.208,0.860$ \\
& 2016 & 3.59 & $1.579,5.60^{*}$ \\
& 2017 & 1.57 & $0.702,2.43^{*}$ \\
& 2018 & 1.63 & $0.709,2.54$ * \\
\hline & Intercept & 0.0560 & $-0.444,0.552$ \\
& Rock & 0.352 & $-0.199,0.904$ \\
& Tree & 0.480 & $-0.142,1.10$ \\
& Treeline & 0.965 & $0.475,1.45^{*}$ \\
& $2014 / 2015$ & 0.317 & $-0.220,0.854$ \\
& $2015 / 2016$ & 3.57 & $1.56,5.58^{*}$ \\
& $2016 / 2017$ & 1.54 & $0.672,2.40^{*}$ \\
& $2017 / 2018$ & 1.61 & $0.689,2.53$ * \\
\hline
\end{tabular}

Estimates are shown on the logit scale. Model intercepts represent subalpine forest in 2014 for the elevation zone + year model and subalpine forest in 2014 with no nurse object for the elevation zone + year + nurse object model. * Indicates $95 \%$ CIs do not overlap zero.

\section{Discussion}

We monitored whitebark pine seedlings that germinated from seeds sown in 2012 on Tibbs Butte, Shoshone National Forest, Wyoming, to estimate ASR and the effects of various site characteristics on survival over time. An additive model incorporating year and elevation zone was the most parsimonious. Given this model, the probability that one or more seedlings would survive in a cache site for five years was 0.273 in subalpine forest and 0.571 at treeline.

\subsection{Implications for Treeline Dynamics under Climate Change}

Treeline elevations are expected to rise as the climate warms. Initial indications of rising treelines include increased regeneration at and above treeline, where it was previously rare or dependent on nurse objects [79-82]. Although climate change is anticipated to decrease the areal extent of whitebark pine's range via loss of climatically suitable areas at lower elevations, core areas of its range are expected to shift northwards and up in elevation in the Rocky Mountains [19-21,83,84]. The mean elevation comprising suitable habitat for whitebark pine within the GYE is expected to shift into current treeline elevations above $3218 \mathrm{~m}$ by 2099 [20], constraining whitebark pine's distribution to high elevation locations in the Wind River Range and on the Beartooth Plateau, where Tibbs Butte is located. Our finding that the odds of whitebark pine seedling survival were 2.62 times higher at treeline relative to within the subalpine forest suggests that upward migration of whitebark pine may have begun and warming may be affecting treeline dynamics near whitebark pine's elevational limits in the GYE. Although higher treeline survival may be the chance result of good year(s), higher odds of seedling survival at treeline $(3.49 ; 95 \%$ CI: $2.03,6.00)$ were apparent after the first winter and do not appear to have diminished over time [45,85-87]. Increased treeline recruitment has been documented elsewhere within whitebark pine's range. For example, Pansing et al. [45] reported that odds of germination of sown seed caches were 3.88 times higher at treeline than in upper subalpine forest at White Calf Mountain in Glacier National Park, possibly indicating that these patterns may exist throughout the Northern Rocky Mountains, although additional studies are necessary to extend these findings to other locations and over longer periods of time.

Temperature affects seed germination, emergence, and establishment at treeline in particular, with warmer winter (i.e., non-growing season) temperatures associated with increased regeneration [80,88-91]. Although we did not estimate weather effects on ASR because we lacked weather data at the same spatial resolution as our sampling unit, temperature and precipitation 
measurements from the Beartooth Lake SNOTEL suggest avenues for further exploration [58]. Consistent with expectations that warmer winter temperatures are associated with increased treeline recruitment, non-growing season median daily average, minimum, and maximum temperatures were highest in 2016, corresponding to the highest ASRs during the study for both subalpine and treeline elevations. If our findings are replicated by others, they would provide empirical support for the alleviation of harsh climatic conditions that previously limited treeline recruitment.

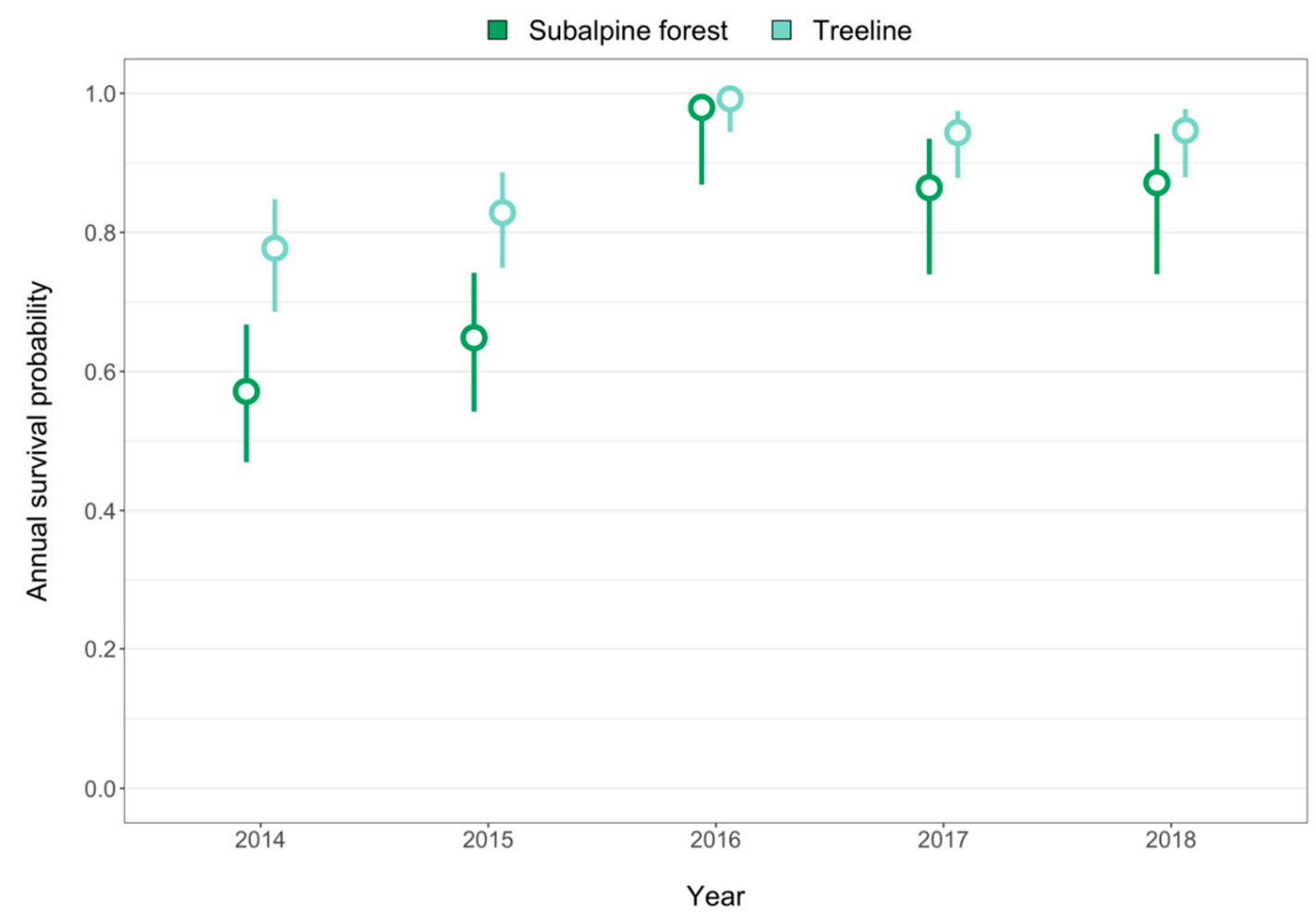

Figure 4. Annual survival probability of directly sown whitebark pine seeds on Tibbs Butte, Shoshone National Forest, Wyoming, USA as described by elevation zone and year. Points show annual survival estimates, and lines show 95\% confidence intervals. The model selected includes the additive effects of elevation zone (subalpine forest vs. treeline) and year. Models were fit in MARK [65] using the RMark [65] package in R [57].

\subsection{Treeline Restoration}

Declining seed availability in upper subalpine forest, the seed source for treeline recruitment, and the presence of WPBR at treeline could adversely affect treeline ecosystem function by reducing the keystone and foundational functions provided by whitebark pine [32,74]. Similar to subalpine restoration efforts, treeline restoration (planting or direct seeding) could compensate for seed source loss in the upper subalpine forest, hasten the spread of WPBR-resistance, and speed up regeneration, thereby improving the probability of continued ecosystem function $[24,32,34,35]$. Our findings that the odds of seedling survival are 2.62 times higher at treeline than in upper subalpine forest suggest that planting seedlings or direct seeding could be an effective conservation action for treeline whitebark pine communities.

Additionally, treeline restoration could be used to mitigate the impacts of climate change. The climatically suitable area for most tree species is expected to move faster than documented rates of conifer movement following the last glaciation [92-94]. Assisted migration has been proposed as a means to facilitate species movement to locations expected to become climatically suitable and increase the probability of population persistence, especially for species where natural migration is unlikely $[95,96]$. Whitebark pine's long generation times and declining seed availability, which reduce 
both dispersal and recruitment potential, make it a candidate for assisted migration. If our findings of high seedling survival rates at treeline are corroborated, seedling planting or direct seeding at locations near or above the current treeline could assist whitebark pine's migration to higher elevations $[20,24,34]$.

\subsection{Increased Moisture Stress Corresponded to Increased Seedling Survival}

In addition to the aforementioned observation that non-growing season temperature is correlated positively with treeline recruitment, we observed that survival was highest during the driest water year, which corresponded to the time period between 1 October 2015 and 30 September 2016 (Figure 1). This observation suggests that drier and warmer conditions may be associated with increased whitebark pine seedling survival at the upper limits of its elevational distribution. Whitebark pine seedlings possess ecophysiological traits including higher water use efficiency and carbon assimilation rates that confer higher tolerance to dry conditions relative to more shade tolerant heterospecifics [97].

In apparent contradiction to these observations, survival was lowest in 2014 and 2015, the second driest and second wettest water years during the study, respectively. This apparent discordance between cumulative precipitation and survival could be a result of survival increasing with seedling age. Seedling mortality risk is thought to be highest in the first few years following emergence; age trends have been documented in whitebark pine and other high elevation conifer species (e.g., [49-51,98]). Because our study design did not allow for the incorporation of weather or age effects, we were unable to disentangle whether lower seedling survival during 2014 and 2015 was a result of seedling age, weather, or their interaction. Better understanding of the variability in seedling survival attributable to weather would help land managers define planting densities that are robust to bad weather years.

\subsection{Nurse Objects}

Recruitment is generally limited by seed availability, which is already declining in many areas because of the combined effects of WPBR and MPB, and/or microsite availability [15,87]. Microsites are often defined by nurse objects that can ameliorate harsh microclimatic conditions [99]. Both higher seed germination and seedling survival have been associated with nurse objects in many studies across a range of species (e.g., $[45,49,74,75,100])$. This information has been incorporated into restoration strategies and studies to improve planting outcomes $[35,101]$. For example, the orientation of planted limber pine ( $P$. flexilis E. James) seedlings around cut sections of boles from downed trees improved seedling health and survival [75]. The first-year survival of the treeline seedlings investigated in this study was improved by the presence of a nurse object [45]; odds of survival increased by 4.53 ( $95 \%$ CI: $1.95,10.5)$ and $8.41(95 \%$ CI: 3.20, 22.1) times near rocks and trees, respectively, relative to no object. Further, current whitebark pine outplanting guidelines recommend planting seedlings on the north side of nurse objects to ameliorate water stress, reduce insolation, and protect seedlings from wind and snow [102,103].

Despite a substantial body of literature showing microsite effects on seedling survival and the fact that the second-best model in this study included nurse object as a cofactor, the 95\% confidence intervals of all object parameters overlapped zero. Thus, it is plausible that there is no difference in ASR among caches created near different nurse objects. However, by the time the most recent surveys were conducted in 2018, there were only a maximum of 9 caches near any single nurse object in the subalpine forest and a maximum of 19 caches near any single nurse object at treeline. This low sample size may have precluded our ability to detect any differences.

\subsection{Direct Seeding Could Be a Viable Restoration Technique for Whitebark Pine}

Compared to seedling planting, whitebark pine restoration using direct seeding could reduce time between seed collection and planting, decrease costs, and increase area available for restoration. Our estimated ASRs, which ranged from 0.571 to 0.992, are consistent with other reported ASRs from seedlings resulting from directly sown seeds and planted seedlings, which range from 0.357 to 0.993 (e.g., [44,46,98,102,103]), assuming constant survival over time. Although our results represent 
findings from a case study and additional research with sufficient replication is needed, the fact that our estimates fall within the existing range of ASRs for whitebark pine suggest they are not unusual and that direct seeding may be a viable restoration option for whitebark pine.

The Greater Yellowstone Coordinating Committee's Whitebark Pine Subcommittee recommends planting 741 whitebark pine trees per ha, which corresponds to a target density of 247 trees per ha after establishment $[102,104]$. Using this target density and assuming that seedlings are "established" (more likely to survive) six years after sowing, we estimated the number of seed caches required to restore one hectare of whitebark pine in subalpine forest and at treeline The estimates considered the proportion of caches pilfered by granivorous rodents, and the proportion of caches that germinated and survived, with the caveat that seedling survival will vary from year to year (i.e., the year effects reported here will likely not be the same with each planting effort). Pansing et al. [45] reported probabilities of 0.452 and 0.351 that all seeds in a cache were pilfered at treeline and in the subalpine forest, respectively, and, germination probabilities of 0.680 and 0.608 , respectively. Using these figures, we estimated cache densities of 1410 (95\% CI: 1134, 2266) and 4229 (95\% CI: 2772, 7609) caches per ha at treeline and in the subalpine forest, respectively, to attain target densities. These figures are likely underestimates. They do not consider delayed germination; we used germination probabilities that only consider germination following one winter of dormancy. Additional measures could be taken to prevent seed pilferage, a key factor limiting direct seeding success. DeMastus [46] found germination and early survival (1-2 years) improved an average of $11.7 \%$ when caches were caged to prevent rodent pilferage. However, the monetary costs of implementation and eventual removal of these cages need to be weighed against potential improvements. Ideally, direct seeding efforts would occur during years with large cone crops to avoid heavy seed loss associated with cache pilferage. Clearly this would be an option only in areas where cone-bearing tree mortality is low, but it could be used to assist migration in areas expected to be strongly impacted by climate change. Recent estimates of nursery expenses for whitebark pine seedling planting range from \$2.28 to \$2.35 USD per seedling, and planting costs range from $\$ 371$ to $\$ 1236$ USD per ha $[42,105]$. Assuming similar costs for both direct seeding and planting and a target density of 247 seedlings per ha, direct seeding would save a minimum of \$563 USD per hectare, reducing costs by $41 \%$. However, planting costs for direct seeding have been estimated only for research purposes, not restoration [105]. A more rigorous cost analysis is required to assess whether seeding would be more economical than seedling planting.

\section{Conclusions}

We found encouraging annual seedling survival rates that suggest direct seeding may be a more efficient restoration technique for whitebark pine than seedling planting. Direct seeding may be especially useful at treeline, where it could facilitate migration to newly climatically suitable areas. However, with only this single case study, we advocate that more direct seeding studies be conducted to confirm our results. Future research needs to include assessments of the relationship between annual weather and direct seeding success, benefits of seeding near nurse objects, optimal number of seeds to plant in each cache, and regional variability in germination and seedling survival. Lastly, realistic cost estimates are necessary to determine whether direct seeding is practical for whitebark pine.

Supplementary Materials: The following are available online at http://www.mdpi.com/1999-4907/10/8/677/s1, Figure S1: Annual survival probability of directly sown whitebark pine seeds on Tibbs Butte, Shoshone National Forest, Wyoming, USA, as described by the additive effects of elevation zone, year, and nurse object.

Author Contributions: E.R.P. collected data and completed all analyses. E.R.P. and D.F.T. designed the study and wrote the manuscript.

Funding: This research received no external funding.

Acknowledgments: We are grateful to Aaron Wagner, T. Ryan McCarley, Kent Houston, and Andrew Boddicker for their field assistance.

Conflicts of Interest: The authors declare no conflict of interest. 


\section{References}

1. Van Mantgem, P.J.; Stephenson, N.L.; Byrne, J.C.; Daniels, L.D.; Franklin, J.F.; Fule, P.Z.; Harmon, M.E.; Larson, A.J.; Smith, J.M.; Taylor, A.H.; et al. Widespread increase of tree mortality tates in the Western United States. Science 2009, 323, 521-524. [CrossRef] [PubMed]

2. Stevens-Rumann, C.S.; Kemp, K.B.; Higuera, P.E.; Harvey, B.J.; Rother, M.T.; Donato, D.C.; Morgan, P.; Veblen, T.T. Evidence for declining forest resilience to wildfires under climate change. Ecol. Lett. 2018, 21, 243-252. [CrossRef] [PubMed]

3. Wong, C.M.; Daniels, L.D. Novel forest decline triggered by multiple interactions among climate, an introduced pathogen and bark beetles. Glob. Chang. Biol. 2017, 23, 1926-1941. [CrossRef] [PubMed]

4. Westerling, A.L.; Hidalgo, H.G.; Cayan, D.R.; Swetnam, T.W. Warming and earlier spring increase Western U.S. forest wildfire activity. Science 2006, 313, 940-943. [CrossRef] [PubMed]

5. Pederson, G.T.; Gray, S.T.; Woodhouse, C.A.; Betancourt, J.L.; Fagre, D.B.; Littell, J.S.; Watson, E.; Luckman, B.H.; Graumlich, L.J. The unusual nature of recent snowpack declines in the North American Cordillera. Science 2011, 333, 332-335. [CrossRef] [PubMed]

6. Raffa, K.F.; Aukema, B.H.; Bentz, B.J.; Carroll, A.L.; Hicke, J.A.; Turner, M.G.; Romme, W.H. Cross-scale drivers of natural disturbances prone to anthropogenic amplification: The dynamics of bark beetle eruptions. Bioscience 2008, 58, 501-517. [CrossRef]

7. Weed, A.S.; Ayres, M.P.; Hicke, J.A. Consequences of climate change for biotic disturbances in North American forests. Ecol. Monogr. 2013, 83, 441-470. [CrossRef]

8. Roy, B.A.; Alexander, H.M.; Davidson, J.; Campbell, F.T.; Burdon, J.J.; Sniezko, R.; Brasier, C. Increasing forest loss worldwide from invasive pests requires new trade regulations. Front. Ecol. Environ. 2014, 12, 457-465. [CrossRef]

9. Lovett, G.M.; Weiss, M.; Liebhold, A.M.; Holmes, T.P.; Leung, B.; Lambert, K.F.; Orwig, D.A.; Campbell, F.T.; Rosenthal, J.; McCullough, D.G.; et al. Nonnative forest insects and pathogens in the United States: Impacts and policy options. Ecol. Appl. 2016, 26, 1437-1455. [CrossRef]

10. Millar, C.I.; Stephenson, N.L. Temperate forest health in an era of emerging megadisturbance. Science 2015, 349, 823-826. [CrossRef]

11. Tomback, D.F.; Achuff, P. Blister rust and western forest biodiversity: Ecology, values and outlook for white pines. For. Pathol. 2010, 40, 186-225. [CrossRef]

12. Shanahan, E.; Irvine, K.M.; Thoma, D.; Wilmoth, S.; Ray, A.; Legg, K.; Shovic, H. Whitebark pine mortality related to white pine blister rust, mountain pine beetle outbreak, and water availability. Ecosphere 2016, 7 , e01610. [CrossRef]

13. Smith, C.M.; Langor, D.W.; Myrholm, C.; Weber, J.; Gillies, C.; Stuart-Smith, J. Changes in white pine blister rust infection and mortality in limber pine over time. Can. J. For. Res. 2013, 43, 90-96. [CrossRef]

14. Buotte, P.C.; Hicke, J.A.; Preisler, H.K.; Abatzoglou, J.T.; Raffa, K.F.; Logan, J.A. Climate influences on whitebark pine mortality from mountain pine beetle in the Greater Yellowstone Ecosystem. Ecol. Appl. 2016, 26, 2507-2524. [CrossRef]

15. Leirfallom, S.B.; Keane, R.E.; Tomback, D.F.; Dobrowski, S.Z. The effects of seed source health on whitebark pine (Pinus albicaulis) regeneration density after wildfire. Can. J. For. Res. 2015, 45, 1597-1606. [CrossRef]

16. Tomback, D.F.; Arno, S.F.; Keane, R.E. The compelling case for management intervention. In Whitebark Pine Communities: Ecology and Restoration; Tomback, D.F., Arno, S.F., Keane, R.E., Eds.; Island Press: Washington, DC, USA, 2001; pp. 3-28.

17. Shepherd, B.; Jones, B.; Sissons, R.; Cochrane, J.; Park, J.; Smith, C.M.; Stafl, N. Ten years of monitoring illustrates a cascade of effects of white pine blister rust and focuses whitebark pine restoration in the Canadian Rocky and Columbia Mountains. Forests 2018, 9, 138. [CrossRef]

18. Nesmith, J.C.B.; Wright, M.; Jules, E.S.; McKinney, S.T. Whitebark and foxtail pine in Yosemite, Sequoia, and Kings Canyon National Parks: Initial assessment of stand structure and condition. Forests 2019, 10, 35. [CrossRef]

19. Schrag, A.M.; Bunn, A.G.; Graumlich, L.J. Influence of bioclimatic variables on tree-line conifer distribution in the Greater Yellowstone Ecosystem: Implications for species of conservation concern. J. Biogeogr. 2008, 35, 698-710. [CrossRef] 
20. Chang, T.; Hansen, A.J.; Piekielek, N. Patterns and variability of projected bioclimatic habitat for Pinus albicaulis in the Greater Yellowstone Area. PLoS ONE 2014, 9, e111669. [CrossRef]

21. Warwell, M.V.; Rehfeldt, G.E.; Crookston, N.L. Modeling contemporary climate profiles of whitebark pine (Pinus albicaulis) and predicting responses to global warming. In Proceedings of the Whitebark Pine: A Pacific Coast Perspective, Ashland, OR, USA, 27-31 August 2006; pp. 139-142.

22. Keane, R.E.; Holsinger, L.M.; Mahalovich, M.F.; Tomback, D.F. Evaluating future success of whitebark pine ecosystem restoration under climate change using simulation modeling. Restor. Ecol. 2017, 25, 220-233. [CrossRef]

23. Romme, W.H.; Turner, M.G. Implications of global climate change for biogeographic patterns in the Greater Yellowstone Ecosystem. Conserv. Biol. 1991, 5, 373-386. [CrossRef]

24. Aitken, S.N.; Yeaman, S.; Holliday, J.A.; Wang, T.; Curtis-McLane, S. Adaptation, migration or extirpation: Climate change outcomes for tree populations. Evol. Appl. 2008, 1, 95-111. [CrossRef]

25. Hutchins, H.E.; Lanner, R.M. The central role of Clark's nutcracker in the dispersal and establishment of whitebark pine. Oecologia 1982, 55, 192-201. [CrossRef]

26. Tomback, D.F. Foraging strategies of Clark's nutcracker. Living Bird 1978, 16, 123-161.

27. Tomback, D.F. Dispersal of whitebark pine seeds by Clark's nutcracker: A mutualism hypothesis. J. Anim. Ecol. 1982, 51, 451-467. [CrossRef]

28. McKinney, S.T.; Tomback, D.F. The influence of white pine blister rust on seed dispersal in whitebark pine. Can. J. For. Res. 2007, 37, 1044-1057. [CrossRef]

29. Barringer, L.E.; Tomback, D.F.; Wunder, M.B.; McKinney, S.T. Whitebark pine stand condition, tree abundance, and cone production as predictors of visitation by Clark's nutcracker. PLoS ONE 2012, 7, e37663. [CrossRef]

30. Tomback, D.F.; Clary, J.K.; Koehler, J.; Hoff, R.J.; Arno, S.F. The effects of blister rust on post-fire regeneration of whitebark pine: The Sundance Burn of Northern Idaho (USA). Conserv. Biol. 1995, 9, 654-664. [CrossRef]

31. Ellison, A.M.; Bank, M.S.; Clinton, B.D.; Colburn, E.A.; Elliott, K.; Ford, C.R.; Foster, D.R.; Kloeppel, B.D.; Knoepp, J.D.; Lovett, G.M.; et al. Loss of foundation species: Consequences for the structure and dynamics of forested ecosystems. Front. Ecol. Environ. 2005, 3, 479-486. [CrossRef]

32. Tomback, D.F.; Resler, L.M.; Keane, R.E.; Pansing, E.R.; Andrade, A.J.; Wagner, A.C. Community structure, biodiversity, and ecosystem services in treeline whitebark pine communities: Potential impacts from a non-native pathogen. Forests 2016, 7, 21. [CrossRef]

33. Tomback, D.F.; Kendall, K.C. Biodiversity losses: The downward spiral. In Whitebark Pine Communities: Ecology and Restoration; Tomback, D.F., Arno, S.F., Keane, R.E., Eds.; Island Press: Washington, DC, USA, 2001; pp. 243-262.

34. Schoettle, A.W.; Sniezko, R.A. Proactive intervention to sustain high-elevation pine ecosystems threatened by white pine blister rust. J. For. Res. 2007, 12, 327-336. [CrossRef]

35. Keane, R.E.; Tomback, D.F.; Aubry, C.A.; Bower, A.D.; Campbell, E.M.; Cripps, C.L.; Jenkins, M.B.; Mahalovich, M.F.; McKinney, S.T.; Murray, M.P.; et al. A Range-Wide Restoration Strategy for Whitebark Pine (Pinus albicaulis); RMRS-GTR-279; USDA Forest Service Rocky Mountain Research Station: Fort Collins, CO, USA, 2012; p. 108.

36. Sniezko, R.A.; Koch, J. Breeding trees resistant to insects and diseases: Putting theory into application. Biol. Invasions 2017, 19, 3377-3400. [CrossRef]

37. Schwandt, J.W.; Lockman, I.B.; Kliejunas, J.T.; Muir, J.A. Current health issues and management strategies for white pines in the western United States and Canada. For. Pathol. 2010, 40, 226-250. [CrossRef]

38. Sniezko, R.A. Resistance breeding against nonnative pathogens in forest trees-Current successes in North America. Can. J. Plant Pathol. 2010, 28, S270-S279. [CrossRef]

39. Burns, K.S.; Schoettle, A.W.; Jacobi, W.R.; Mahalovich, M.F. Options for the Management of White Pine Blister Rust in the Rocky Mountain Region; RMRS-GTR-206; U.S. Department of Agriculture, Forest Service, Rocky Mountain Research Station: Fort Collins, CO, USA, 2008; p. 26.

40. Burr, K.E.; Eramian, A.; Eggleston, K. Growing whitebark pine seedlings for restoration. In Whitebark Pine Communities: Ecology and Restoration 1; Tomback, D.F., Arno, S.F., Keane, R.E., Eds.; Island Press: Washington, DC, USA, 2001; pp. 325-345. 
41. Mahalovich, M.F.; Dickerson, G.A. Whitebark pine genetic restoration program for the Intermountain West (United States). In Proceedings of the IUFRO Working Party: Breeding and Genetic Resources of Five-Needle Pines: Growth, Adaptability and Pest Resistance, Medford, OR, USA, 23-27 July 2001; Sniezko, R.A., Samman, S., Schlarbaum, S.E., Kriebel, H.B., Eds.; RMRS-P-32. USDA Forest Service, Rocky Mountain Research Station: Fort Collins, CO, USA, 2004; pp. 181-187.

42. Tomback, D.F.; Achuff, P.; Schoettle, A.W.; Schwandt, J.W.; Mastrogiuseppe, R.J. The magnificent high-elevation five-needle white pines: Ecological roles and future outlook. In The Future of High-Elevation Five-Needle Pines in Western North America, Proceedings of the High Five Symposium, Missoula, MT, USA, 28-30 June 2010; Keane, R.E., Tomback, D.F., Murray, M.P., Smith, C.M., Eds.; RMRS-P-63; USDA Forest Service, Rocky Mountain Research Station: Fort Collins, CO, USA, 2011; pp. 2-28, ISBN 1570-0232.

43. Keane, R.E. The importance of wilderness to whitebark pine research and management. In Proceedings of the Wilderness Science in a Time of Change Conference, Missoula, MT, USA, 23-27 May 1999; McCool, S.F., Cole, D.N., Borrie, W.T., O'Loughlin, J., Eds.; RMRS-P-15-VOL-3. USDA Forest Service, Rocky Mountain Research Station: Ogden, UT, USA, 2000; pp. 84-92.

44. Shoal, R.; Ohlson, T.; Aubry, C. Land Managers Guide to Whitebark Pine Restoration in the Pacific Northwest Region 2009-2013; USDA Forest Service, Pacific Northwest Region: Portland, OR, USA, 2008; p. 46.

45. Pansing, E.R.; Tomback, D.F.; Wunder, M.B.; French, J.P.; Wagner, A.C. Microsite and elevation zone effects on seed pilferage, germination, and seedling survival during early whitebark pine recruitment. Ecol. Evol. 2017, 7, 9027-9040. [CrossRef]

46. DeMastus, C.R. Effective Methods of Regenerating Whitebark Pine (Pinus albicaulis) through Direct Seeding; Masters of Science, Montana State University: Bozeman, MT, USA, 2013.

47. Schwandt, J.W.; Chadwick, K.; Kearns, H.; Jensen, C. Whitebark pine direct seeding trials in the Pacific Northwest. In The Future of High-Elevation Five-Needle Pines in Western North America, Proceedings of the High Five Symposium, Missoula, MT, USA, 28-30 June 2011; Keane, R.E., Tomback, D.F., Murray, M.P., Smith, C.M., Eds.; RMRS-P-63; USDA Forest Service, Rocky Mountain Research Station: Fort Collins, CO, USA, 2011; pp. 357-361.

48. Schwandt, J.W.; Tomback, D.F.; Keane, R.E.; McCaughey, W.W.; Kearns, H.S.J. First year results of a whitebark pine seed planting trial near Baker City, OR. In Proceedings of the Conference Whitebark Pine: A Pacific Coast Perspective, Ashland, OR, USA, 27-31 August 2006; Goheen, E.M., Sniezko, R.A., Eds.; Pacific Northwest Region, Forest Service, U. S. Department of Agriculture: Portland, OR, USA; pp. 132-138.

49. Maher, E.L.; Germino, M.J. Microsite differentiation among conifer species during seedling establishment at alpine treeline. Ecoscience 2006, 13, 334-341. [CrossRef]

50. McCaughey, W.W.; Tomback, D.F. The natural regenerration process. In Whitebark Pine Communities: Ecology and Restoration; Tomback, D.F., Arno, S.F., Keane, R.E., Eds.; Island Press: Washington, DC, USA, 2001; pp. 105-120.

51. Mellmann-Brown, S. The Regeneration of Whitebark Pine in the Timberline Ecotone of the Beartooth Plateau, Montana and Wyoming. Ph.D. Dissertation, Westfälischen Wilhelms-Universität, Münster, Germany, 2002.

52. Wagner, A.C.; Tomback, D.F.; Resler, L.M.; Pansing, E.R. Whitebark pine prevalence and ecological function in treeline communities of the Greater Yellowstone Ecosystem, USA: Potential disruption by white pine blister rust. Forests 2018, 9, 635. [CrossRef]

53. National Park Service-Park Unit Boundaries. Available online: https://public-nps.opendata.arcgis.com/ datasets/national-park-service-park-unit-boundaries?geometry=-135.857\%2C38.031\%2C-74.817\%2C49. 124 (accessed on 10 June 2019).

54. USDA Forest Service. National Forest Administrative Units in the GYE. Available online: https://www. sciencebase.gov/catalog/item/58518df6e4b0f99207c4f136 (accessed on 10 June 2019).

55. Kahle, D.; Wickham, H. ggmap: Spatial Visualization with ggplot2. R J. 2013, 5, 144-161. [CrossRef]

56. Wickham, H. ggplot2: Elegant Graphics for Data Analysis (Use R!), 2nd ed.; Springer: New York, NY, USA, 2016; ISBN 978-0-387-98140-6.

57. R Core Team. R: A Language and Environment for Statistical Computing; R Foundation for Statistical Computing: Vienna, Austria, 2018.

58. National Resource Conservation Service SNOTEL. Available online: https://wcc.sc.egov.usda.gov/nwcc/site? sitenum=326 (accessed on 11 June 2019). 
59. Frich, P.; Alexander, L.V.; Della-Marta, P.; Gleason, B.; Haylock, M.; Tank Klein, A.M.G.; Peterson, T. Observed coherent changes in climatic extremes during the second half of the twentieth century. Clim. Res. 2002, 19, 193-212. [CrossRef]

60. Mahalovich, M.F.; Hipkins, V.D. Molecular Genetic Variation in Whitebark Pine (Pinus albicaulis Engelm.) in the Inland West. In The Future of High-Elevation, Five-Needle White Pines Western North America, Proceedings of the High Five Symposium, Missoula, MT, USA, 28-30 June 2010; Keane, R.E., Tomback, D.F., Murray, M.P., Smith, C.M., Eds.; RMRS-P-63; USDA Forest Service, Rocky Mountain Research Station: Fort Collins, CO, USA, 2011; pp. 118-132, ISBN 1570-0232.

61. ESRI. ArcGIS Desktop: Release 10; Environmental Systems Research Institute: Redlands, CA, USA, 2011.

62. Tomback, D.F.; Sund, S.K.; Hoffmann, L.A. Post-fire regeneration of Pinus albicaulis: Height-age relationships, age structure, and microsite characteristics. Can. J. For. Res. 1993, 23, 113-119. [CrossRef]

63. Furnier, G.R.; Knowles, P.; Clyde, M.A.; Dancik, B.P. Effects of avian seed dispersal on the genetic structure of whitebark pine populations. Evolution 2006, 41, 607-612. [CrossRef]

64. Tomback, D.F.; Linhart, Y.B. The evolution of bird-dispersed pines. Evol. Ecol. 1990, 4, 185-219. [CrossRef]

65. Laake, J.L. RMark: An R Interface for Analysis of Capture-recapture Data with MARK; AFSC Processed Report; NOAA: Seattle, WA, USA, 2013.

66. White, G.C.; Burnham, K.P. Program mark: Survival estimation from populations of marked animals. Bird Study 1999, 46, S120-S139. [CrossRef]

67. Pollock, K.H.; Winterstein, S.R.; Conroy, M.J. Estimation and analysis of survival distributions for radio-tagged animals. Biometrics 1989, 45, 99-109. [CrossRef]

68. Kaplan, E.L.; Meier, P. Nonparametric estimation from incomplete observations. J. Am. Stat. Assoc. 1958, 53, 457-481. [CrossRef]

69. Chamberlain, T.C. The Method of Multiple Working Hypotheses and the Agony of Choice. Science 1890, 15, 92-96.

70. Burnham, K.P.; Anderson, D.R.; Huyvaert, K.P. AIC model selection and multimodel inference in behavioral ecology: Some background, observations, and comparisons. Behav. Ecol. Sociobiol. 2011, 65, 23-35. [CrossRef]

71. Burnham, K.P.; Anderson, D.R. Model Selection and Multimodel Inference: A Practical Information-Theoretic Approach, 2nd ed.; Springer: Berlin, Germany, 2002; ISBN 0-387-95364-7.

72. Dochtermann, N.A.; Jenkins, S.H. Developing multiple hypotheses in behavioral ecology. Behav. Ecol. Sociobiol. 2011, 65, 37-45. [CrossRef]

73. Petrie, M.D.; Wildeman, A.M.; Bradford, J.B.; Hubbard, R.M.; Lauenroth, W.K. A review of precipitation and temperature control on seedling emergence and establishment for ponderosa and lodgepole pine forest regeneration. For. Ecol. Manag. 2016, 361, 328-338. [CrossRef]

74. Tomback, D.F.; Blakeslee, S.C.; Wagner, A.C.; Wunder, M.B.; Resler, L.M.; Pyatt, J.C.; Diaz, S. Whitebark pine facilitation at treeline: Potential interactions for disruption by an invasive pathogen. Ecol. Evol. 2016, 6, 5144-5157. [CrossRef]

75. Casper, A.M.A.; Jacobi, W.R.; Schoettle, A.W.; Burns, K.S. Restoration planting options for limber pine (Pinus flexilis James) in the Southern Rocky Mountains. J. Torrey Bot. Soc. 2016, 143, 21-37. [CrossRef]

76. Resler, L.M.; Tomback, D.F. Blister rust prevalence in krummholz whitebark pine: Implications for treeline dynamics, Northern Rocky Mountains, Montana, USA. Arctic Antarct. Alp. Res. 2008, 40, 161-170. [CrossRef]

77. Tomback, D.F.; Chipman, K.G.; Resler, L.M.; Smith-McKenna, E.K.; Smith, C.M. Relative abundance and functional role of whitebark pine at treeline in the Northern Rocky Mountains. Arctic Antarct. Alp. Res. 2014, 46, 407-418. [CrossRef]

78. Tomback, D.F.; Anderies, A.J.; Carsey, K.S.; Powell, M.L.; Mellmann-Brown, S. Delayed seed germination in whitebark pine and regeneration patterns following the Yellowstone fires. Ecology 2001, 82, 2587-2600. [CrossRef]

79. Grace, J.; Berninger, F.; Nagy, L. Impacts of climate change on the tree line. Ann. Bot. 2002, 90, 537-544. [CrossRef]

80. Harsch, M.A.; Hulme, P.E.; McGlone, M.S.; Duncan, R.P. Are treelines advancing? A global meta-analysis of treeline response to climate warming. Ecol. Lett. 2009, 12, 1040-1049. [CrossRef]

81. Holtmeier, F.-K.; Broll, G. Treeline advance-Driving processes and adverse factors. Landsc. Online 2007, 1, 1-33. [CrossRef] 
82. Malanson, G.P.; Butler, D.R.; Fagre, D.B.; Walsh, S.J.; Tomback, D.F.; Daniels, L.D.; Resler, L.M.; Smith, W.K.; Weiss, D.J.; Peterson, D.L.; et al. Alpine treeline of Western North America: Linking organism-to-landscape dynamics. Phys. Geogr. 2007, 28, 378-396. [CrossRef]

83. Coops, N.C.; Waring, R.H. Estimating the vulnerability of fifteen tree species under changing climate in Northwest North America. Ecol. Modell. 2011, 222, 2119-2129. [CrossRef]

84. Hansen, A.; Ireland, K.; Legg, K.; Keane, R.E.; Barge, E.; Jenkins, M.; Pillet, M. Complex challenges of maintaining whitebark pine in Greater Yellowstone under climate change: A call for innovative research, management, and policy approaches. Forests 2016, 7, 54. [CrossRef]

85. Ibáñez, I.; Clark, J.S.; LaDeau, S.; Hille Ris Lambers, J. Exploiting temporal variability to understand tree recruitment response to climate change. Ecol. Monogr. 2007, 77, 163-177. [CrossRef]

86. Andersen, A.N. How important is seed predation to recruitment in stable populations of long-lived perennials? Oecologia 1989, 81, 310-315. [CrossRef]

87. Eriksson, O.; Ehrlén, J. Seed and microsite limitation of recruitment in plant populations. Oecologia 1992, 91, 360-364. [CrossRef]

88. Elliott, G.P. Extrinsic regime shifts drive abrupt changes in regeneration dynamics at upper treeline in the Rocky Mountains, USA. Ecology 2012, 93, 1614-1625. [CrossRef]

89. Kullman, L.; Öberg, L. Post-Little Ice Age tree line rise and climate warming in the Swedish Scandes: A landscape ecological perspective. J. Ecol. 2009, 97, 415-429. [CrossRef]

90. Kullman, L. Tree line population monitoring of Pinus sylvestris in the Swedish Scandes, 1973-2005: Implications for tree line theory and climate change ecology. J. Ecol. 2007, 95, 41-52. [CrossRef]

91. Millar, C.I.; Westfall, R.D.; Delany, D.L. Response of subalpine conifers in the Sierra Nevada, California, U.S.A., to 20th-century warming and decadal climate variability. Arctic Antarct. Alp. Res. 2004, 36, 181-200. [CrossRef]

92. Hamann, A.; Wang, T. Potential effects of climate change on ecosystem and tree species distribution in British Columbia. Ecology 2006, 87, 2773-2786. [CrossRef]

93. Loarie, S.R.; Duffy, P.B.; Hamilton, H.; Asner, G.P.; Field, C.B.; Ackerly, D.D. The velocity of climate change. Nature 2009, 462, 1052-1055. [CrossRef]

94. Liang, Y.; Duveneck, M.J.; Gustafson, E.J.; Serra-Diaz, J.M.; Thompson, J.R. How disturbance, competition, and dispersal interact to prevent tree range boundaries from keeping pace with climate change. Glob. Chang. Biol. 2018, 24, e335-e351. [CrossRef]

95. McLane, S.C.; Aitken, S.N. Whitebark pine (Pinus albicaulis) assisted migration potential: Testing establishment north of the species range. Ecol. Appl. 2012, 22, 142-153. [CrossRef]

96. Roberts, D.R.; Hamann, A. Climate refugia and migration requirements in complex landscapes. Ecography 2016, 39, 1238-1246. [CrossRef]

97. Bansal, S.; Reinhardt, K.; Germino, M.J. Linking carbon balance to establishment patterns: Comparison of whitebark pine and Engelmann spruce seedlings along an herb cover exposure gradient at treeline. Plant Ecol. 2011, 212, 219-228. [CrossRef]

98. Cripps, C.L.; Alger, G.; Sissons, R. Designer niches promote seedling survival in forest restoration: A 7-year study of whitebark pine (Pinus albicaulis) seedlings in Waterton Lakes National Park. Forests 2018, 9, 477. [CrossRef]

99. Pyatt, J.C.; Tomback, D.F.; Blakeslee, S.C.; Wunder, M.B.; Resler, L.M.; Boggs, L.A.; Bevency, H.D. The importance of conifers for facilitation at treeline: Comparing biophysical characteristics of leeward microsites in whitebark pine communities. Arctic Antarct. Alp. Res. 2016, 48, 427-444. [CrossRef]

100. Schupp, E.W. Seed-seedling conflicts, habitat choice, and patterns of plant recruitment. Am. J. Bot. 1995, 82, 399-409. [CrossRef]

101. Douterlungne, D.; Ferguson, B.G.; Siddique, I.; Soto-Pinto, L.; Jímenez-Ferrer, G.; Gavito, M.E. Microsite determinants of variability in seedling and cutting establishment in tropical forest restoration plantations. Restor. Ecol. 2015, 23, 861-871. [CrossRef]

102. Scott, G.L.; McCaughey, W.W. Whitebark pine guidelines for planting prescriptions. In National Proceedings of the Forest and Conservation Nursery Associations; RMRS-P-43; USDA Forest Service, Rocky Mountain Research Station: Fort Collins, CO, USA, 2006; pp. 84-90.

103. McCaughey, W.W.; Scott, G.L.; Izlar, K.L. Whitebark pine planting guidelines. West. J. Appl. For. 2009, 24, 163-166. 
104. Greater Yellowstone Coordinating Committee. Whitebark Pine Subcommittee Whitebark Pine Strategy for the Greater Yellowstone Area; Greater Yellowstone Coordinating Committee: Bozeman, MT, USA, 2011.

105. Jungck, E.; USDA Forest Service. Personal communication, 2019.

(C) 2019 by the authors. Licensee MDPI, Basel, Switzerland. This article is an open access article distributed under the terms and conditions of the Creative Commons Attribution (CC BY) license (http://creativecommons.org/licenses/by/4.0/). 